\title{
Evaluation of molecular genetic diagnosis in the management of familial adenomatous polyposis coli: a population based study
}

E R Maher, D E Barton, R Slatter, D J Koch, $M$ H Jones, $H$ Nagase, S J Payne, $S$ J Charles, A T Moore, Y Nakamura, M A Ferguson-Smith

\begin{abstract}
A population based clinical and molecular genetic study of familial adenomatous polyposis coli (FAPC) was performed to investigate the value of molecular genetic analysis and ophthalmological assessment in the presymptomatic diagnosis of FAPC. The point prevalence of affected patients was $2.62 \times 10^{-5}(1 / 38000)$ and the minimum heterozygote prevalence was estimated at $3.8 \times 10^{-5}(1 / 26000)$. Eight of $33(24 \%)$ probands were new mutations. Fortyeight asymptomatic relatives at $50 \%$ prior risk aged between 10 and 40 years were assessed for risk modification with linked DNA markers: in nine subjects $(\mathbf{1 8 \%})$ the family structure was unsuitable for linkage based analysis, but 32 subjects were informative with a panel of intragenic and closely linked markers (25 had a combined age/DNA related risk of $<1 \%$ (low risk group) and seven were at high risk (DNA predicted risk $\mathbf{3} 99 \%$ )). Ophthalmological assessment for CHRPEs showed that $27 / 43(63 \%)$ affected patients and high risk relatives and $0 /$ 18 low risk relatives had more than three CHRPEs. Interfamilial variation in CHRPE expression was apparent. This study has shown that DNA based risk modification with intragenic and closely linked DNA markers is informative in most FAPC families. In addition to the clinical benefits of presymptomatic diagnosis for FAPC, the reduction in screening for low risk relatives (365 person years in the present study) means that molecular genetic diagnosis of FAPC is a cost effective procedure.

( $\mathcal{3}$ Med Genet 1993;30:675-8)
\end{abstract}

Familial adenomatous polyposis coli (FAPC) is a dominantly inherited disorder characterised by the development of numerous (at least 100) colorectal polyps. Age at onset is variable, but polyps usually develop in teenage years and penetrance is almost complete at the age of 40 years. ${ }^{1}$ Colorectal carcinoma develops inevitably unless prophylactic colectomy is performed. Polyps may also occur in the upper gastrointestinal tract, and although the risk of malignant transformation is probably lower than for colonic adenomas, duodenal carcinoma is now emerging as an important cause of death in patients with FAPC. ${ }^{2}$ Extraintestinal manifestations of FAPC include epidermoid cysts, osteomas, desmoid tumours, and, most frequently, congenital hypertrophy of the retinal pigment epithelium (CHRPE).

FAPC is caused by mutations in the APC gene in chromosome 5q21-q22.3-5 Presymptomatic bowel screening of at risk relatives considerably reduces morbidity and mortality from FAPC, ${ }^{67}$ and the efficiency of screening can be enhanced by reliable presymptomatic diagnosis of FAPC gene carriers with linked DNA markers and ophthalmological assessment for CHRPEs ${ }^{89}$ However, presymptomatic detection of FAPC gene carriers is limited by (1) significant recombination between the DNA markers in general use, and (2) uncertainty about the sensitivity and accuracy of CHRPEs. The isolation and characterisation of the APC gene ${ }^{3-5}$ should lead to more accurate presymptomatic diagnosis by the identification of new intragenic and very closely linked DNA markers. We report a population based study of the clinical and molecular genetics of FAPC.

\section{Methods}

PATIENTS

Affected patients and at risk relatives were ascertained by contacting gastroenterologists, surgeons, and general practitioners in East Anglia (population 2058 951). All affected patients had $>100$ polyps. At risk relatives were offered screening (by annual sigmoidoscopy or three yearly colonoscopy) starting between 11 and 15 years of age and continuing to the age of 40 years. Ophthalmological assessment for CHRPE was performed by a single ophthalmologist. At risk subjects aged between 11 and 40 years were offered DNA based risk modification when the family structure was suitable for genetic linkage analysis.

\section{MOLECULAR GENETIC ANALYSIS}

Blood was collected from relevant family members and genomic DNA prepared from peripheral blood lymphocytes by standard techniques. Five polymorphic DNA markers were investigated: (1) a $3^{\prime}$ SspI polymorphism (DP2.5) in the APC gene, ${ }^{10}(2)$ an exon $11 R s a I$ polymorphism (APC-E11) in the APC gene, ${ }^{11}$ (3) a microsatellite polymorphism (L5.71) at the MCC locus (Jones and Nakamura, in preparation), (4) a MspI RFLP at D5S81 (YN5.48), ${ }^{12}$ and (5) a BglII RFLP at D5S98 (ECB27) ${ }^{13}$ DNA was digested with the appropriate restriction enzyme according to the 


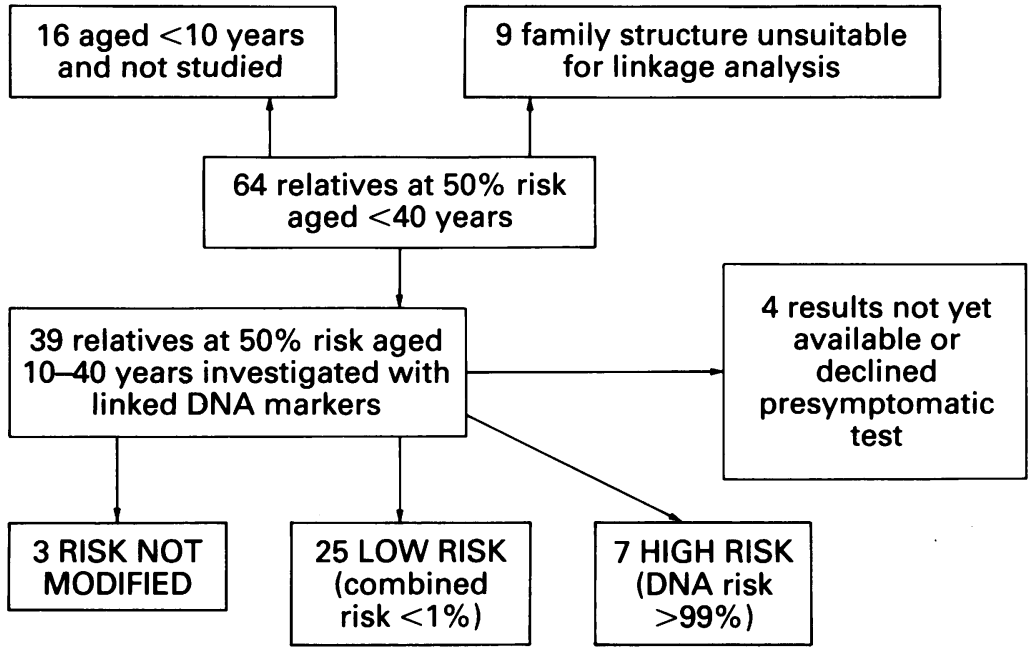

Summary of the results for presymptomatic diagnosis for FAPC in East Anglia. Full details are given in the text. relatives informative for DNA analysis (see below) living in East Anglia. There were 30/39 $(77 \%)$ affected patients and $7 / 22(32 \%)$ at risk relatives with one or more CHRPEs, and 24/39 $(57 \%)$ and $3 / 22(14 \%)$ respectively had four or more CHRPEs. Of the 22 relatives informative for DNA analysis who underwent ophthalmological assessment, 18 were found to be at low risk (combined age and DNA related risk of $<1 \%$ ) and four were high risk (99\%). The frequency of CHRPEs varied between families. In the 14 families in which at least one affected patient had more than three CHRPEs $27 / 29(93 \%)$ affected patients/high risk relatives and $0 / 12$ low risk relatives had more than three CHRPEs. In the nine families in which none of 13 affected patients had more than three CHRPEs, none of the at risk relatives (one high, six low risk) had more than three CHRPEs.

manufacturers' recommendations. For ECB27 and YN5.48 agarose gel electrophoresis Southern transfer, and hybridisation with ${ }^{32} \mathrm{P}$ labelled probe was performed as described previously. ${ }^{14}$ For two intragenic markers (APC-exon $11 R s a I$ and DP2.5) and the CA repeat polymorphism in L5.71, DNA was amplified by the polymerase chain reaction under the appropriate conditions (Jones and Nakamura, in preparation) $)^{1011}$ and the alleles resolved in an agarose gel for the intragenic markers and on a $6 \%$ polyacrylamide $/ 6 \mathrm{M}$ urea sequencing gel for L5.71. Families were initially investigated with the two intragenic polymorphisms, and then with the highly informative dinucleotide repeat L5.71 which maps approximately $300 \mathrm{~kb}$ centromeric to the APC gene. Uninformative families were then studied with YN5.48 and ECB27. The locus order is: ECB27-L5.71-APC-YN5.48. DNA related risks were calculated using the MLINK program with the following recombination fractions: APC exon 11 RsaI $\theta=0.001$, DPD2.5 $\theta=0.001$, L5.71 $\theta=0.005$, YN5.48 $\theta=0.02$, and ECB27 $\theta=0.03$. A final carrier risk was derived by a Bayesian calculation combining the age related and DNA based risks. The age related risk was based on the age at last sigmoidoscopy/colonoscopy and the published age dependent penetrance classes. ${ }^{15}$

\section{Results}

CLINICAL GENETIC ANALYSIS

At the start of the study there were 54 affected patients and 64 relatives aged $<40$ years at $50 \%$ prior risk (that is, had an affected parent) from 33 kindreds living in East Anglia. The crude prevalence of FAPC patients in East Anglia was $2.62 \times 10^{-5}(1 / 38000)$. By estimating the number of gene carriers among asymptomatic at risk relatives and the prevalence of asymptomatic new mutation FAPC patients aged $<20$ years, it was calculated that the heterozygote prevalence in East Anglia is at least $3.8 \times 10^{-5}(1 / 26000)$. Eight of 54 affected patients represented new mutations.

Ophthalmological assessment was performed in 39 affected patients and 22 at risk

\section{CYTOGENETIC ANALYSIS}

High resolution cytogenetic analysis was perpatients, but one affected patient with moderate mental retardation, minor dysmorphic features, and multiple $(>10)$ CHRPEs showed an apparently balanced complex translocation: $46,(X Y), t(5 ; 12 ; 16)(5 p t e r \rightarrow 5 q 22:: 12 q 22 \rightarrow 12-$ qter; 12 pter $\rightarrow 12 \mathrm{q} 22:: 5 \mathrm{q} 32 \rightarrow 5 \mathrm{q} 22:: 16 \mathrm{q} 11.2 \rightarrow 16$ qter;16pter $\rightarrow 16 \mathrm{q} 11 \cdot 2:: 5 \mathrm{q} 32 \rightarrow 5 \mathrm{qter}), \mathrm{t}(9 ; 1)(\mathrm{q} 33$; q14). Both parents had normal chromosomes

\section{GENETIC LINKAGE ANALYSIS}

Twenty-two of 26 kindreds had a suitable structure for linkage based risk modification. These kindreds contained 39 subjects at $50 \%$ prior risk aged between 10 and 40 years and 38 of these requested investigation for risk modification by linked DNA markers. After molecular investigation with the protocol described previously, 32 relatives were informative, three are still being studied, and DNA testing did not significantly alter the risk of three subjects (figure). The three uninformative subjects ( $1, T 1$, and $T 2)$ were from two families in which the family structure was not optimal for linkage based analysis. In the 32 informative relatives, all those at low risk had a combined age/DNA related risk of $<1 \%$ and all high risk subjects had a DNA predicted risk of $>99 \%$. The results of DNA marker analysis for individual relatives are shown in the table. The dinucleotide (CA) repeat polymorphism in L5.71 was the most informative, with $77 \%$ (17/22) of subjects investigated being informative. The two intragenic polymorphisms (exon $11-R s a \mathrm{I}$ and DP2.5) were informative in $55 \%$ $(18 / 33)$ and $46 \%(13 / 28)$ of subjects, but the two polymorphisms were in linkage disequilibrium (observed haplotype frequencies in 59 individual chromosomes: $1 / 1=0 / 59,1 / 2=23$ / $\left.59,2 / 1=31 / 59,2 / 2=5 / 59, \chi^{2}=38 \cdot 4, p<0.0001\right)$, which reduced the overall informativeness of these two markers.

No evidence of FAPC has been detected in formed in four mentally retarded FAPC patients. Chromosomes were normal in three and phenotype. 
Presymptomatic diagnosis of FAPC using linked DNA markers: summary of 35 cases aged 10 to 40 years informative for DNA analysis. Details of risk calculations are given in the Methods section. Key to intragenic markers: E11 = exon $11 \mathrm{RsaI}$ polymorphism in APC gene, DP2.5=3' SspI polymorphism in APC gene.

\begin{tabular}{|c|c|c|c|c|c|}
\hline \multirow{2}{*}{$\begin{array}{l}\text { Identification } \\
\text { No }\end{array}$} & \multicolumn{2}{|c|}{ DNA markers investigated } & \multicolumn{3}{|c|}{ Carrier risks (\%) } \\
\hline & Informative & Not informative & $\begin{array}{l}\text { Age } \\
\text { related }\end{array}$ & DNA & Final \\
\hline$A, 1$ & L5.71 & $\begin{array}{l}\text { E11, DP2.5, YN5.48, } \\
\text { ECB27 }\end{array}$ & 9 & 1 & $0 \cdot 1$ \\
\hline A,2 & L5.71, E11, DP2.5 & YN5.48, ECB27 & 13 & $0 \cdot 2$ & 0.03 \\
\hline A,3 & L5.71 & E11, DP2.5, YN5.48 & 13 & $99 \cdot 5$ & $96 \cdot 7$ \\
\hline $\mathrm{B}, 1$ & E11, DP2.5 & & 1 & $0 \cdot 1$ & 0.001 \\
\hline $\mathbf{B}, 2$ & E11, DP2.5 & & 13 & $0 \cdot 1$ & 0.02 \\
\hline $\mathrm{C}, 1$ & L5.71 & $\mathrm{E} 11, \mathrm{DP} 2.5, \mathrm{ECB}$ & 50 & 99.5 & 99.5 \\
\hline $\mathrm{C}, 2$ & L5.71 & E11, DP2.5, ECB & 50 & 0.5 & 0.5 \\
\hline $\mathrm{D}, 1$ & E11, L5.71 & DP2.5 & 50 & $0 \cdot 2$ & $0 \cdot 2$ \\
\hline $\mathrm{D}, 2$ & E11, L5.71 & DP2.5 & 50 & 0.2 & 0.2 \\
\hline $\mathrm{D}, 3$ & L5.71 & & 33 & 1 & $0 \cdot 3$ \\
\hline$D, 4$ & L5.71 & E11, DP2.5 & 50 & 1 & 1 \\
\hline $\mathrm{E}, 1$ & E11, DP2.5 & & 33 & $0 \cdot 14$ & 0.07 \\
\hline $\mathrm{E}, 2$ & E11, DP2.5 & & 33 & 99.9 & $99 \cdot 8$ \\
\hline $\mathrm{E}, 3$ & E11, DP2.5 & & 33 & 99.9 & $99 \cdot 8$ \\
\hline $\overrightarrow{\mathrm{F}, 1}$ & E11 & ECB, YN5.48 & 9 & 0.02 & 0.002 \\
\hline $\mathrm{G}, 1$ & E11, DP2.5, YN5.48 & $\mathrm{ECB}$ & 1 & 6 & $0 \cdot 1$ \\
\hline $\mathrm{G}, 2$ & E11, DP2.5, YN5.48 & ECB & 1 & 6 & $0 \cdot 1$ \\
\hline $\mathrm{H}, 1$ & E11, DP2.5, L5.71 & ECB, YN5.48 & 9 & $0 \cdot 2$ & 0.02 \\
\hline $\mathrm{J}, 1$ & L5.71 & E11, DP2.5, ECB & 50 & $99 \cdot 1$ & $99 \cdot 1$ \\
\hline $\mathrm{J}, 2$ & L5.71 & & 33 & 1 & 0.3 \\
\hline $\mathrm{K}, 1$ & YN5.48 & E11, DP2.5, ECB & 1 & 2 & 0.02 \\
\hline $\mathrm{K}, 2$ & E11, YN5.48 & DP2.5, ECB & 1 & $0 \cdot 1$ & 0.001 \\
\hline $\mathrm{L}, 1$ & L5.71 & E11, DP2.5, ECB & 9 & 98 & \\
\hline $\mathrm{L}, 2$ & L5.71 & E11, DP2.5, ECB & 13 & 2 & 0.3 \\
\hline$M, 1$ & L5.71 & E11 & 1 & 1 & 0.01 \\
\hline$N, 1$ & E11 & L5.71, ECB & 20 & $0 \cdot 2$ & 0.06 \\
\hline $\mathrm{N}, 2$ & & E11, L5.71, ECB & 13 & 50 & \\
\hline N,3 & & E11, L5.71, ECB & 13 & 50 & 13 \\
\hline $\mathbf{P}, 1$ & E11, DP2.5, L5.71 & ECB & 9 & $0 \cdot 2$ & 0.02 \\
\hline $\mathbf{P}, 2$ & L5.71 & E11, DP2.5, ECB & 9 & 0.6 & 0.06 \\
\hline $\mathrm{Q}, 1$ & E11, DP2.5 & & 13 & $0 \cdot 2$ & 0.1 \\
\hline $\mathrm{Q}, 2$ & $\mathrm{E} 11, \mathrm{DP} 2.5$ & & 1 & 0.2 & 0.002 \\
\hline $\mathbf{R}, \mathbf{1}$ & E11, DP2.5, YN5.48 & L5.71, ECB & 50 & $99 \cdot 6$ & $99 \cdot 6$ \\
\hline S,1 & & $\begin{array}{l}\text { E11, DP2.5, L5.71, ECB, } \\
\text { YN5 } 48\end{array}$ & 50 & 50 & \\
\hline$S, 2$ & E11, DP2.5 & & 50 & $\begin{array}{ll}30 \\
0 \cdot 1\end{array}$ & $0 \cdot 1$ \\
\hline
\end{tabular}

the 25 low risk subjects; 18 of these have undergone ophthalmological assessment with negative findings (fewer than four CHRPEs) (see above). Four high risk subjects have been investigated by sigmoidoscopy or colonoscopy, two had no polyps at the ages of 14 and 16, and polyps were detected in two aged 18 and 27 years.

\section{Discussion}

EPIDEMIOLOGY

The ascertainment of affected patients $\left(2.62 \times 10^{-5}\right)$ in East Anglia compares favourably to that in north-east England $(2.29 \times$ $\left.10^{-5}\right),{ }^{8}$ Finland, ${ }^{7}$ Denmark $\left(2.6 \times 10^{-5}\right),{ }^{16}$ and Western Australia $(2.59 \times 10-5) .{ }^{17}$ The prevalence of FAPC appears to be increasing because of better case ascertainment and increased survival as a result of more patients being diagnosed early through presymptomatic screening programmes. ${ }^{67}$ We estimated a minimum heterozygote prevalence of $1 / 26000$ $\left(3.8 \times 10^{-5}\right)$. Our estimate that $24 \%$ of probands represented new mutations is similar to that at the Cleveland Clinic $(22 \%),{ }^{18}$ but less than the $46 \%$ of probands in the Netherlands reported by Vasen et al. ${ }^{6}$ Although it has been suggested that new mutations may be associated with a more severe phenotype, ${ }^{18}$ a meaningful comparison is difficult because isolated cases will be diagnosed later.

CARRIER DETECTION

Although four patients with FAPC and cytogenetically visible chromosome $5 \mathrm{q}$ deletions have been reported, ${ }^{19-22}$ to our knowledge we have reported the first FAPC patient with a reciprocal translocation apparently involving the APC gene. Although chromosomal aberrations are rare in FAPC, cytogenetic analysis should be performed in all mentally retarded FAPC patients and those with a family history of mental handicap. Only a minority of such patients will prove to have a chromosomal rearrangement, but the benefits of identifying such patients are considerable.

Most reports of DNA based presymptomatic diagnosis in FAPC are of selected families $^{152324}$ but such studies do not accurately reflect the range of families seen in routine clinical practice. Population based studies are more representative, but MacDonald et al found that only $46 \%$ of at risk relatives in the English West Midlands had a suitable family structure for genetic linkage analysis, only $12 \%$ of subjects tested were informative for flanking markers, and the recombination fractions for the DNA markers studied ranged from 3 to $10 \%$. We used recently identified intragenic and closely linked DNA markers and found that in those families with a suitable structure for linkage based analysis, the status of most at risk relatives can be established accurately. However, $18 \%(9 / 48)$ of at risk relatives were from families in which the family structure was unsuitable for this type of analysis or in which DNA from key family members was not available. Presymptomatic diagnosis by direct mutation detection may be applicable in such families and we have characterised the APC gene mutations in 15/24 East Anglian kindreds analysed. ${ }^{25}$ However, the 
spectrum of APC gene mutations is extremely heterogeneous and although some clustering of APC gene mutations exists (for example, at codons 1309 and 1061), ${ }^{25-27}$ the complete detection of APC gene mutations would represent a formidable amount of work. The best strategy for the molecular genetic investigation of FAPC is not yet established but we suspect that genetic linkage analysis will be the initial investigation in families with a suitable structure. The observation that most APC gene mutations result in a truncated protein ${ }^{25}$ suggests that the most promising diagnostic approach might be the use of antibodies against the APC gene product.

The presence of multiple CHRPEs can be used as a biomarker for the presymptomatic diagnosis of FAPC. The specificity of four or more CHRPEs for FAPC appears to be high. Burn et $a l^{8}$ found that $0 / 94$ normal subjects and we found $0 / 18$ low risk relatives had more than three CHRPEs. However, Cachon-Gonzalez et $a l^{23}$ reported a single person with five CHRPEs who was at low risk with flanking DNA markers (Pi227 and YN5.48). CHRPE analysis provides a method of independently confirming the results of molecular genetic analysis, but further studies are needed to determine the molecular basis for interfamilial differences in the frequency of CHRPEs.

\section{COST-BENEFIT ANALYSIS}

We have not attempted to perform a detailed cost-benefit analysis of our programme (such an analysis would have to quantify the benefit of reassuring at risk relatives as well as the prevention of colorectal cancers, etc); however, it is possible to estimate the reduction in screening produced by identifying low risk subjects. We estimate that by discontinuing screening in the 25 low risk relatives we will avoid 365 person years of unnecessary screening. The cost of a single colonoscopy has been estimated as $£ 107,,^{28}$ so for a screening programme based on three yearly colonoscopy (the most frequently used protocol in East Anglia), a saving of 365 person years translates into a future financial saving of approximately $£ 13000$ at current costing.

We thank the many physicians and surgeons who referred their patients, Marie FergusonSmith, Lionel Willatt, Margaret Leversha, and Kay Cook for cytogenetic analysis, and the East Anglian Public Health and Operational Research Fund for financial support.

1 Murday V, Slack J. Inherited disorders associated with colorectal cancer. Cancer Surv 1989;8:139-57.

2 Jagelman $D$. The expanding spectrum of familial adenomatous polyposis. Perspect Colon Rectal Surg 1988;1:30-46.
3 Kinzler KW, Nilbert MC, Vogelstein B, et al. Identification of a gene located at chromosome 5q21 that is mutated in colorectal cancers. Science 1991;251:1366-70.

4 Nishisho I, Nakamur. Ycience $1991 ; 251: 1366-70$. chromosome 5q21 genes in FAP and colorectal cancer chromosome 5q21 genes in FAP

5 Groden J, Thliveris A, Samowitz W, et al. Identification and characterization of the familial adenomatous polyposis coli gene. Cell 1991;66:589-600.

6 Vasen HF, Griffioen G, Offerhaus GJ, et al. The value of screening and central registration of families with familia adenomatous polyposis. A study of 82 families in The Netherlands. Dis Colon Rectum 1990;33:227-30.

7 Járvinen HJ. Epidemiology of familial adenomatous polyposis in Finland: impact of family screening on the colorectal cancer rate and survival. Gut 1992;33:357-60.

8 Burn J, Chapman P, Delhanty J, et al. The UK Northern region genetic register for familial adenomatous polyposis coli: use of age of onset, congenital hypertrophy of the retinal pigment epithelium, and DNA matations. F Med Genet 1991;28:289-96.

9 MacDonald F, Morton DG, Rindl PM, et al. Predictive diagnosis of familial adenomatous polyposis with linked DNA markers: population based study. BMF DNA markers:

10 Heighway J, Hoban PR, Wyllie AH. Sspl polymorphism in sequence encoding $3^{\prime}$ untranslated region of the APC gene. Nucleic Acids Res 1991;19:6966.

11 Kraus C, Ballhausen WG. Two intragenic polymorphisms of the APC-gene detected by PCR and enzymatic digestion. Hum Genet 1992;88:705-6.

12 Nakamura $Y$, Lathrop $M$, Leppert $M$, et al. Localization of the genetic defect in familial adenomatous polyposis within a small region of chromosome 5. Am 7 Hum Genet 1988;43:638-44.

13 Varesco L, Thomas HJW, Cotrell S, et al. CpG island clones from a deletion encompassing the gene for adenomatous polyposis coli. Proc Natl Acad Sci USA 1989;86:10118-22.

14 Maher ER, Bentley E, Yates JRW, et al. Mapping of the von Hippel-Lindau disease locus to a small region of von Hippel-Lindau disease locus to a small region of chromosome 3p

15 Dunlop MG, Wyllie AH, Steel CM, Piris J, Evans HJ. Linked DNA markers for presymptomatic diagnosis of familial adenomatous polyposis. Lancet 1991;337:313-6.

16 Bülow S, Holm NV, Hauge M. The incidence and prevalence of polyposis coli in Denmark. Scand $\mathcal{f}$ Soc Med 1986;14:67-74.

17 Bower C, Levitt S, Francis S. The Western Australian Familial Polyposis Registry. Med f Aust 1989;151:557-8.

18 Rustin RB, Jagelman DG, McGannon E, Fazio VW, Lavery IC, Weakley FL. Spontaneous mutation in familial adenomatous polyposis. Dis Colon Rectum 1990;33:52-5.

19 Herrera L, Carrel A, Rao U, Castillo N, Petrelli N. Familial adenomatous polyposis in association with thyroiditis. Report of two cases. Dis Colon Rectum 1989;32:893-6.

20 Hockey KA, Mulcahy MT, Montgomery P, Levitt S Deletion of chromosome 5q and familial adenomatous Deletion of chromosome $5 \mathrm{q}$ and fam
polyposis. $\mathcal{F}$ Med Genet 1989;26:61-2.

21 Cross I, Delhanty J, Chapman P, et al. An intrachromosomal insertion causing 5q22 deletion and familial adenomatous polyposis coli in two generations. 7 Med Gene 1992;29:175-9.

22 Lindgren V, Bryke CR, Ozcelik T, Yang-Feng TL Francke U. Phenotypic, cytogenetic, and molecular studies of three patients with constitutional deletions of chromosome 5 in the gene for familial adenomatous polyposis. Am $\mathcal{F}$ Hum Genet 1992;50:988-97.

23 Cachon-Gonzalez MB, Delhanty JD, Burn J, et al. Linkage analysis in adenomatous polyposis coli: the use of four closely linked DNA probes in $20 \mathrm{UK}$ families. $f \mathrm{Med}$ Genet 1991;28:681-5.

24 Tops CM, Wijnen JT, Griffionen G, et al. Presymptomatic diagnosis of familial adenomatous polyposis by bridging DNA markers. Lancet 1989;ii:1361-3.

25 Nagase H, Miyoshi Y, Hirii A, et al. Screening for germlike mutations in familial adenomatous polyposis (FAP) patients: 61 new patients and a summary of 150 unrelated patients. Mutat Res (in press).

26 Fodde R, Luijt van der R, Wijnen J, et al. Eight nove inactivating germ line mutations at the APC gene identified by denaturing gradient gel electrophoresis. Genomics 1992;13:1162-8.

27 Cottrell S, Bicknell D, Kaklamanis L, Bodmer WF. Molecular analysis of APC mutations in familial adenomatous polyposis and sporadic colon carcinomas. Lancet 1992;340:626-30.

28 Walker A, Whynes DK, Chamberlain JO, Hardcastle JD The hospital costs of diagnostic procedures for colorectal cancer. $\mathcal{f}$ Clin Epidemiol 1991;44:907-14. 